\title{
Study on mechanical parameters of different densities printed structures
}

\author{
Badanie parametrów mechanicznych \\ struktur drukowanych o różnym zagęszczeniu
}

JERZY MADEJ
MATEUSZ ŚLIWKA *
DOI: https://doi.org/10.17814/mechanik.2017.11.184

\begin{abstract}
Based on the strength tests of porous structure specimen printed in FDM technology (fused deposition modeling) from PC/ABS filaments, numerical simulations of bending elastic beams for two different filling densities, have been performed. The results of numerical analyzes have been verified experimentally and compared with those obtained with the commercial strength parameters of the raw material used for printing. Conducted and planned studies will allow to develop a methodology for calculating the porous structure created in 3D printing technology.
\end{abstract}

KEYWORDS: 3D printing, strength tests, numerical modeling

Recently used traditional technology for the manufacture of plastic and metal components has been supplemented by 3D printing technology, which is especially suitable for the production of no serial or prototype products. The ability of today's 3D printers to create any structure and shape using a variety of starting materials is impressive and developmental, and the products obtained by this method are subject to a number of studies and analyzes [1-4].

One of the most commonly used plastic printing technology is the FDM (fused deposition modeling) method, which involves depositing a layer of molten wire made of commercial material with known properties through the printer head. In this way, an element of the desired shape and required internal structure is obtained.

The 3D printing technology allows for the production of porous components, which limits the amount of raw material used, but the mechanical properties of the final product deviate from that of the same uniform product.

In the case of simulating the construction of porous structures at different load conditions, it is reasonable to assume material constants differing from those of the material, from which the construction was printed.

\section{Subject of study}

This paper discusses:

- calculation model of printed beams that have been subjected to elastic bending;

\footnotetext{
* Dr hab. inż. Jerzy Madej (juma@ath.bielsko.pl), inż. Mateusz Śliwka (sliwkamateuszjan@gmail.com) - Akademia Techniczno-Humanistyczna w Bielsku-Białej
}

- experimental verification of results obtained by numerical simulation;

- comparison of the results from simulation with those from calculations, in which the constants of the filament materials used for printing were accepted.

The test subjects are printed beams of two different compaction: LOW (low) and MED (medium), made of PC/ABS filaments with a Young modulus of $2250 \mathrm{MPa}$ and Poisson's number of 0.4. The geometrical model of the specimen is shown in fig. 1 and the view of the internal structure of beams - fig. 2 .

Thickness of the inner lattice is $0.3 \mathrm{~mm}$, thickness of the upper and lower cover is $0.7 \mathrm{~mm}$ and the side cover is $1.5 \mathrm{~mm}$.

As a result of the attempted static stretching of the paddle specimen for each compaction, Young's replacement module $E_{z}$ was determined. In the case of LOW compacting, it amounted to $1933 \mathrm{MPa}$ and in case of MED compacting - $1897 \mathrm{MPa}$. Resulting values are therefore lower than the filament Young's modulus.

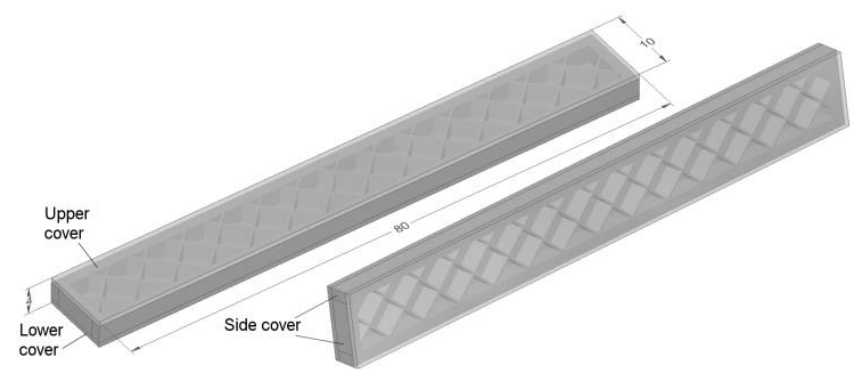

Fig. 1. Geometric model of specimen

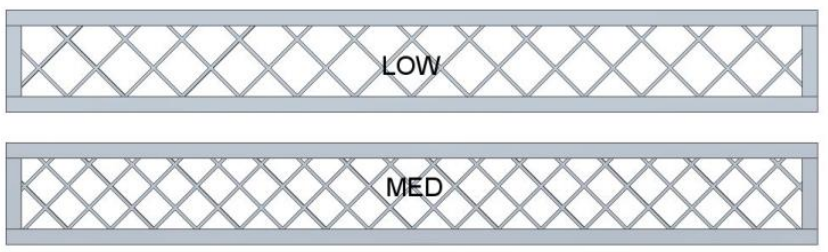

Fig. 2. View of the internal structure of specimen

\section{Measurement of deflection of bending beams}

The three-point bending was performed according to the standard [5] at a speed of $2 \mathrm{~mm} / \mathrm{min}$. The ratio of the 
specimen thickness to the spacing of the supports was $1: 16$ (the spacing of the supports was $64 \mathrm{~mm}$ ).

The three-point bending station is shown in fig. 3 .

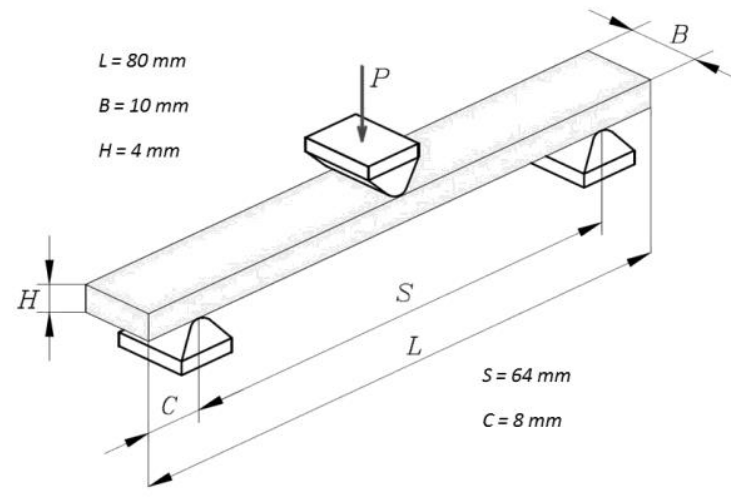

Fig. 3. Three-point bending station diagram

For the purpose of deflection values recording, the wall of the specimen of $80 \times 4 \mathrm{~mm}$ was blackened markers were applied every $4 \mathrm{~mm}$ to the prepared surface (starting from the center of the specimen).

The test for each compaction was done in a series of five specimen on the Inspekt 5 Table Blue universal testing machine by Hegewald und Peschke (fig. 4). The specimen bending at the markers was recorded using Delta Optical BioLight 300 and then the values of these deflections were determined in Delta Optical Smart Analysis Pro software (fig. 5). Mean deflection measurement at the marker points is shown in table I.

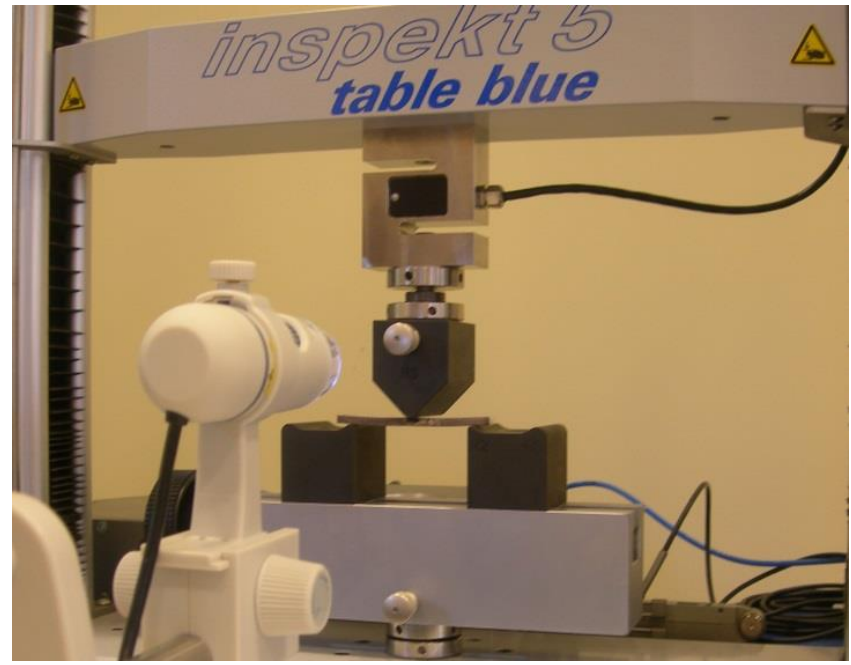

Fig. 4. Examination of specimen on the Inspekt 5 Table Blue universal testing machine

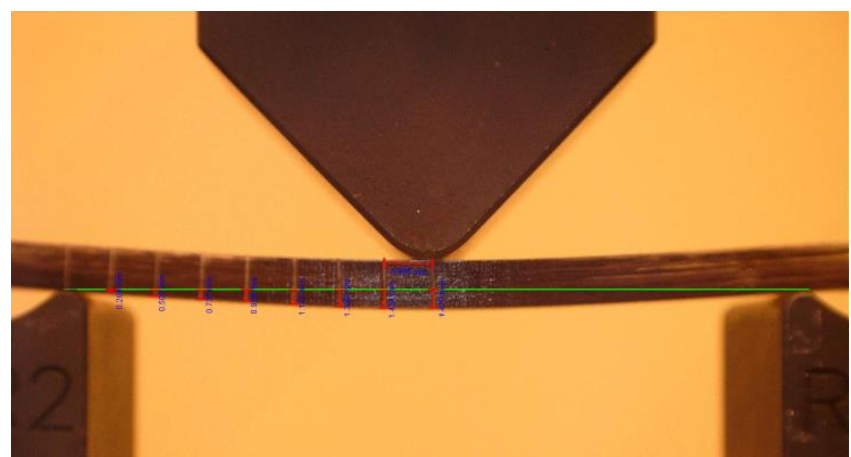

Fig. 5. Image of the bent specimen with the measurement of markers deflection
TABLE I. Average deflections of selected beam points

\begin{tabular}{|c|c|c|}
\hline $\begin{array}{c}\text { Marker position } \\
\mathrm{mm}\end{array}$ & $\begin{array}{c}\text { Average deflection for } \\
\text { specimen LOW }\end{array}$ & $\begin{array}{c}\text { Average deflection for } \\
\text { specimen MED }\end{array}$ \\
\hline 32 & 0 & 0 \\
\hline 28 & 0,269 & 0,257 \\
\hline 24 & 0,504 & 0,503 \\
\hline 20 & 0,736 & 0,734 \\
\hline 16 & 0,950 & 0,954 \\
\hline 12 & 1,152 & 1,156 \\
\hline 8 & 1,321 & 1,317 \\
\hline 4 & 1,443 & 1,428 \\
\hline 0 & 1,480 & 1,464 \\
\hline
\end{tabular}

\section{Numerical analysis}

The discrete model, used for finite element calculations, was prepared in FEMAP 11.2 software. The internal lattice was modeled with PLATE elements, and the cover was made with SOLID elements. Fig. 6 shows a discrete model with a MED compaction (top cover was not shown to visualize the beam's internal structure). In table II, numbers and types of discrete structure elements were compared.

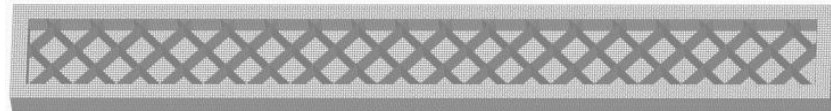

Fig. 6. Discrete model of beam with compaction MED

\section{TABLE II. Number and type of elements}

\begin{tabular}{|c|c|c|c|}
\hline \multirow{2}{*}{$\begin{array}{c}\text { Type of } \\
\text { compaction }\end{array}$} & \multirow{2}{*}{$\begin{array}{c}\text { Number of } \\
\text { nodes }\end{array}$} & \multicolumn{2}{|c|}{ Number of elements } \\
\cline { 3 - 4 } & 183711 & 118560 & 10900 \\
\hline LOW & 194629 & 118560 & 14480 \\
\hline MED & & \multicolumn{2}{|c}{} \\
\hline
\end{tabular}

Supports were provided in a $64 \mathrm{~mm}$ span. At the center of the beam span, a force of $20 \mathrm{~N}$ was applied, causing the beam to bend in the elastic range. At the point of the force application, an additional locking support was applied along the beam axis.

Two computational models were prepared - for LOW and MED compaction. Calculations for each model were conducted in two variants. In the first variant, the Young's replacement module, determined in the tensile test, was assigned to the discrete models, and in the second variant, the elasticity modulus of the filament was assumed.

As a result of calculations, the nodes displacement corresponding to the measurement points in the experiment were obtained, allowing the numerical model to be validated.

Fig. 7 shows the deflection line obtained from the computation for the MED compaction beam. The blue lines indicate the deflections obtained for the replacement modulus of elasticity, the red line - the results obtained for the filament elasticity module, and the black line - the results of the experiment. The graphs for the LOW compaction beam were also identical. As it can be seen, the deflections calculated using the filament elasticity module are outside the confidence interval $\alpha=$ 0.05 .

Table III shows the deflection arrow values calculated for each of the variants and they were compared with the values determined experimentally. 


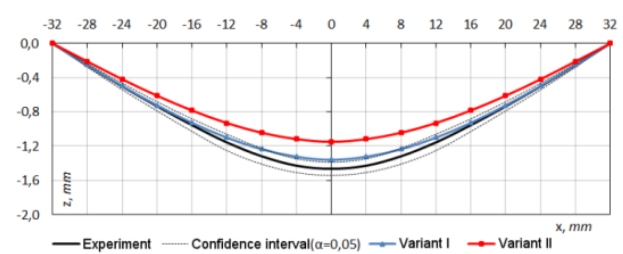

Fig. 7. Deflection line for beams with MED compaction (replacement modulus of elasticity was assumed in variant I, and filament elasticity modulus in variant II)

TABLE III. Comparison of arrow deflection of beams

\begin{tabular}{|c|c|c|c|c|c|}
\hline \multirow{2}{*}{$\begin{array}{c}\text { Type of } \\
\text { specimen }\end{array}$} & \multirow{2}{*}{$\begin{array}{c}\text { Experi- } \\
\text { ment }\end{array}$} & \multicolumn{3}{|c|}{$\begin{array}{c}\text { Variant I } \\
\text { for } E_{z}\end{array}$} & \multicolumn{2}{|c|}{$\begin{array}{c}\text { Variant II } \\
\text { for } E \text { filament }\end{array}$} \\
\cline { 2 - 6 } & $\begin{array}{c}\text { deflection } \\
\mathrm{mm}\end{array}$ & $\begin{array}{c}\text { deflection } \\
\mathrm{mm}\end{array}$ & $\begin{array}{c}\text { error } \\
\%\end{array}$ & $\begin{array}{c}\text { deflection } \\
\mathrm{mm}\end{array}$ & $\begin{array}{c}\text { error } \\
\%\end{array}$ \\
\hline LOW & 1,480 & 1,347 & 8,99 & 1,155 & 21,96 \\
\hline MED & 1,464 & 1,360 & 7,10 & 1,149 & 21,52 \\
\hline
\end{tabular}

\section{Conclusions}

Materials produced by 3D printing change their mechanical properties with respect to the material, from which the filament was made. Static stretching has shown that LOW compaction specimen have higher replacement longitudinal modulus as compared to MED compaction specimen.

By comparing the results of numerical analysis of elastic bending with the experimental results, it can be seen that the adoption in calculation of the replacement Young's module, determined for a specimen of a particular internal structure, results in similar measurements. In the case of a LOW compaction structure, the relative percentage error does not exceed $9 \%$ and for MED, it is $7 \%$. In both cases, the calculated deflections are slightly smaller than those measured. If the Young's filament module is adopted for calculations, the result is an error of more than $21 \%$ and the deflections are significantly smaller.

In conclusion, it can be stated that, for the calculation models of printed structures with different degrees of material density, the experimental material characteristics of printed structure must be taken into account for calculations, not the material characteristics of the filament.

\section{REFERENCES}

1. Miazio Ł. „Badanie wytrzymałości na rozciąganie próbek wydrukowanych technologią FDM z różną gęstością wypełnienia". Mechanik. 7 (2015): pp. 533-538.

2. Miazio $Ł$. „Badanie wytrzymałości na zginanie próbek wydrukowanych technologią FDM z różną gęstością wypełnienia". Mechanik. 7 (2016): pp. 758-759.

3. Miazio Ł. „Badanie wytrzymałości na rozciąganie próbek wydrukowanych $w$ technologii FDM z różną gęstością wypełnienia - wypełnienie heksagonalne i koncentryczne". XXI Międzynarodowa Szkoła Komputerowego Wspomagania Projektowania, Wytwarzania i Eksploatacji, Jurata (2017): pp. 55-60.

4. Kiński W., Pietkiewicz P., Nalepa K., Miąskowski W. „Porównanie wytrzymałości na rozciąganie próbek kompozytowych wydrukowanych w technologii FDM z próbkami wydrukowanymi z PLA". XXI Międzynarodowa Szkoła Komputerowego Wspomagania Projektowania, Wytwarzania i Eksploatacji, Jurata (2017): pp. 297-303.

5. DIN EN ISO 178 Plastics determination of flexural properties (2003). 